\title{
SOME MEDIGAL MEMORIES OF TWO WORLD WARS
}

\author{
BY \\ HUMPHREY HUMPHREYS* \\ Late Vice-Chancellor, University of Birmingham
}

Mr. Haslam, in whose memory this oration is given, was a man of most lovable character, one of those of whom it can truly be said that he had not an enemy in the world, and his familiar nickname of "Uncle" signifies the universal affection which he inspired. Trained at St. Thomas' Hospital in London, he was appointed Assistant Surgeon to the Birmingham General Hospital in 1882 and remained on the staff till the end of the First World War, when he retired ; but not to a life of leisure, for he became Dean of the Medical Faculty and remained so for ten years. Your invitation to deliver this oration recalled old memories of his teaching, and I reflected that his career in some ways resembled my own for I, too, after practising for many years as a surgeon-of sortsfinished up as an administrator in this university. But we had another experience in common : we both served in the Royal Army Medical Corps of the Territorial Army throughout the First World War. In my own case I remained on the active list of that army till 1949 and I have, therefore, chosen as my theme a comparison of the British medical services in the two world wars in each of which I served for four years overseas.

It is commonly believed that the more lethal character of modern weapons has led to a great increase in the numbers killed in modern battles. But this belief is not borne out by the facts. Livy records that 50,000 Romans were killed at the battle of Cannæ (216 B.C.), all in hand-to-hand fighting in a single day. I had occasion not long ago to investigate the battle of Edgehill, the first of the Civil War, fought in Warwickshire on a Sunday afternoon late in October, 1643. The battle was not joined till three o'clock with a bare two hours of daylight left, the forces actually engaged probably numbered well under 20,000 men; no artillery was used, and all the fighting was at close quarters. Next day over 1,000 dead were buried on the battlefield, and there is no record of those who died as the result of the wounds they received. No battle in the last war records such a high percentage of killed in so short a time.

What has occurred since then is a great reduction in the numbers of deaths suffered by armies from sickness and this is directly due to. advances in medical science. There are no reliable figures to illustrate this earlier than the Crimean War, in which the British losses from disease outnumbered those from enemy bullets by 10 to 1 . The actual figures were 16,300 to 1,750 , dysentery, typhus, typhoid and cholera being the chief killers. In the Sino-Japanese war of 1894,

* Professor Humphreys will be better known to some of our readers as Colonel $H$. F. Humphreys, O.B.E., M.C., T.D., who had a distinguished career in the Territorial Army until his retirement in 1949. Colonel Humphreys was Honorary Physician to the King from 1934 to 1949. His article is reprinted from the Queen's Medical Magazine (Birmingham) by kind permission of the Editor. 
the Japanese lost four men from disease to one from wounds; in the South African War of 1899-1902 the corresponding British figure was 2 to $1(14,000$ to 8,000 ). But the recent lessons of those two wars were not lost on the Japanese and in their war with Russia in 1904-5 the figures were reversed; the battle losses were four times as numerous as those from disease, the reduction in which was brought about mainly by sterilization of drinking water, proper disposal of refuse, and better rations.

By 1914 these lessons had been learnt by the British, and they were further aided by some new discoveries such as that of T.A.B. vaccine introduced by Almroth Wright in 1908. There is not, of course, time in a short lecture to give an accurate or detailed survey of the medical services in the two world wars, and it will be more interesting if $I$ give, in general, round figures and use as illustrations my personal experiences. The size of the British Army in the last year of both wars-1918 and 1944 -was much the same, about $4 \frac{1}{2}$ million men. The first war lasted for 51 months, the second 68 , and it may seem surprising that the casualties of 1914-18 should have been far heavier than those for 1939-45. At the end of the one we mourned a million dead, almost exactly a million, of whom no less than a quarter $(247,000)$ were numbered as missing as late as March, 1920, and can, therefore, be confidently counted amongst the killed. In 1946 this toll of the dead was just under a quarter of a million, to which we should add a high proportion of the 53,000 then missing. A tally of the wounded tells the same tale-2,100,000 in the first war, 277,000 in the second-roughly one-eighth of the former total in a war which lasted one-third as long again. This figure in itself shows that the main cause of the contrast in mortality between the two wars lay in the different conditions of combat; continuously at close quarters in the main theatre during World War I, intermittent and more mobile in World War II.

None the less, credit can be claimed by the medical services for part of the improvement. The years between the wars and the war years themselves had seen remarkable, indeed unprecedented, advances in medical science, some of which, such as the advent of the sulpha drugs, penicillin, D.D.T., and mepacrine - to name the most important-were directly applicable to Army problems. The complete medical history of the war has not yet been published, but it will be worth while to look at a few figures that are available and I shall consider chiefly the two theatres in which I myself served in one war or the other, the Middle East and South-East Asia.

Typhoid Fever.- The T.A.B. vaccine was introduced in 1908, but the British with their characteristic consideration for conscientious dissenters did not make it legally compulsory in the 1914-18 war. None the less, the vast majority of soldiers serving abroad in that war received it and typhoid, which in the Boer War had killed more men than enemy bullets, slew in 1914-18 only a little over 1,000 men, practically all unvaccinated. In 1939-45 the injection of T.A.B. vaccine was more strictly enforced, and this is shown by a comparison of the case incidence for typhoid in the Middle East : 3.07 per thousand in 1917, 0.74 per thousand in 1944. 
Dysentery has always been a major scourge of armies. There is a graphic account by Joinville, one of St. Lewis' crusaders, of the destruction of his army by this disease, resulting in his capture by the Saracens. Attention to water supplies and improved camp sanitation did much to reduce it in both world wars by comparison with earlier campaigns. But a high proportion of the native population in the Middle East, India and South-East Asia are dysentery carriers, a substantial number of British troops who recover from dysentery become carriers for a time, and if either of these classes of personnel handle food supplies, food vessels or food implements, dysentery can be conveyed. Probably, indeed, this is today the main method of spread for the disease, whether amobic or bacillary, and its incidence amongst troops in the Middle East was much the same in both wars. But improved methods of treatment, in particular the introduction of sulphaguanidine, greatly reduced the case mortality which, in 1917, was 3.2, in 1944 only 0.02 per cent. This factor of the carrier is perhaps today the most important and the most difficult of solution of the problems of epidemic disease. One striking example emerged in the Middle East where the incidence of jaundice following the treatment of syphilis by arsenical drugs became so. high (43 per cent. of cases early in 1943) that it was thought to be an effect of the drug. The introduction of stricter methods for sterilizing and handling the syringes completely eliminated it. Infective hepatitis was the principal epidemic in that theatre.

Malaria.-In South-East Asia, where I served during 1944 and 1945, malaria was responsible for one-half of the total sickness rate and was, therefore, the most serious drain on the strength of both armies in that theatre-ourselves and the Japanese. But when the Fourteenth Army advanced into Burma towards the end of 1944 it had been convincingly demonstrated by Hamilton Fairley that a regular daily dose of mepacrine, though it did not, of course, prevent infection, would suppress symptoms and thus greatly reduce the casualties. Because it produced in most cases mild symptomless jaundice which was accompanied by slight loss of libido, the belief became current amongst troops that regular mepacrine impaired virility, and this led to widespread evasion of the daily dose. If placed on the tongue at a parade by an officer or orderly, it was slipped into the cheek instead of being swallowed, and spat out subsequently. Indian troops often saved the unswallowed tablets and later sold them to civilians for substantial sums. Finally, the responsibility was placed squarely on the shoulders of C.Os. of units, who were deprived of their command if their incidence of malaria rose above 5 per cent. After this, techniques were soon evolved which insured that the daily dose of mepacrine really was swallowed, and this was a most important factor in the reconquest of Burma by the Fourteenth Army in the winter and spring of 1944-5. The opposing armies were not greatly different in strength, the Japanese were masters of jungle warfare, but they were far more ravaged by sickness than ourselves. For they relied in the treatment and suppression of malaria on the relatively ineffective quinine of which they had a monopoly after their conquest of Java, where most of the world's supply was grown. More than 100,000 dead were 
abandoned, unburied by the Japanese, in their six months' retreat-a high proportion of their total strength. The moral of this tale is the value of a satisfactory liaison between the medical and the fighting services of the Army, and the necessity for educating troops in the reasons for the rules of hygiene they are expected to observe. In that connection it is significant that in South-East Asia the evacuation rate for malaria was three and a half times as high for other ranks as it was for officers, since the rationale of regular mepacrine and antimalarial measures was better appreciated by the latter.

It would be tedious to mention all the other scourges of war that have decimated armies in the past. Most of them-plague, cholera, diphtheria, yellow fever and typhus-had been mastered before 1914 so far as the British Army was concerned and were not important causes of casualties in either war. It is a significant contrast that in 1915 the Serbian Army, whose sanitary standards were much lower, lost one-quarter of its strength from typhus in six months. 1939-45 registered some advances. In both wars the first winter witnessed an extensive outbreak of cerebro-spinal meningitis, due to the overcrowding of newly recruited troops in billets and quarters, and many cases of pneumonia. In 1914-15 the death rate was high, in 1.939-40 negligible owing to the use of sulpha drugs. Tetanus toxoid gave a satisfactory immunity and abolished the necessity for anti-tetanic serum after every wound, and this brings us to the question of surgery in the two wars where the contrasts are greater than in medicine.

\section{SURGERY}

The antibiotics, particularly the availability of penicillin in the latter part of the war when most of the heavy fighting took place, produced a dramatic change in the prospects of recovery from wounds. Equally important was the availability of blood banks and plasma in forward hospitals. Landsteiner had demonstrated the main blood groups before World War I and blood transfusions were employed in its hospitals, but on nothing like the extensive scale that was made possible in World War II. In 1914 there was little understanding of shock and it was all too often fatal. During 1939-45 the universal availability of whole blood and plasma transfusion deprived shock of its position as captain of the kings of death in the surgical wards. With the antibiotics and blood transfusion went improvements in surgical technique. The most dramatic of these was that of complete immobilization of compound fractures by plaster of Paris, the excision of damaged and infected tissue, and then a rest for the wound instead of the frequent irrigations by Carrel Dakin solution which had been the fashion in 1916-18, or the antiseptic applications which were common in the early part of that war. This new technique had been first demonstrated on a large scale by Trueta in Barcelona during the Spanish civil war. He claimed to have treated 20,000 compound fractures with only 91 bad results and only four amputations. The essence of it was the provision of rest for the damaged tissues, and this ideal was made more easy of attainment by an enormous improvement in the methods of collecting and evacuating wounded which the second war 
shows, when compared with the first. I believe that this factor has been insufficiently appreciated in discussions of the medical services. It was, of course, due to the greatly improved methods of transport that had become available, and I can best illustrate it by an account of my personal experiences.

In both wars I served with armies operating in areas not well suited for transport, Sinai, Palestine and Syria in the first war, South-East Asia in the second. In the battles late in 1917 which resulted in the capture of Jerusalem I was D.A.D.M.S. of the Yeomanry Mounted Division. In that campaign, and still more in the advance on Damascus the following year, cavalry played an important, indeed a decisive, part-the last war in which it is ever likely to do so. After the Turkish line between Gaza and Beersheba was turned in October, 1917, the cavalry rode ahead and my division advanced up the valley of Ajalon-where, you may remember, the sun stood still for Joshua in a battle over 3,000 years earlier, where David pursued the Philistines from Gideon even unto Gezer, where Judas Maccabæus, the Romans, and the Crusaders had all in turn advanced on Jerusalem. Our object was to cut the road which ran along the crest of the Judaean highland and supplied Jerusalem from the north. As soon as we left the plains at Ramleh and began to climb, the going got steadily worse, and by the second day wheeled transport became impossible : guns and ambulances had to be left behind and all we had for the transport of wounded were camels carrying cacolets-a form of double litter, one on each side of the hump. Very soon the track became so choked with boulders that we all dismounted and led our horses. Opposition began to stiffen, we were over 2,000 feet up and very cold, being clad in light khaki drill, while most of the men had had nothing to eat all day. The next day we advanced again, but in the afternoon, when four miles from our objective, we were heavily attacked by a Turkish infantry division supported by artillery, and had to retire a few miles. Luckily it was getting dusk and the Turks did not follow us up, which enabled myself and two field ambulance officers with their bearer sections to collect the wounded, while a thin rear-guard held off the enemy patrols. We had about thirty camels which took the worst casualties and the others, about a hundred, had to ride on horses, even some with broken legs. That is, they rode in the dark along a rough track which sound men in daylight had negotiated dismounted. We made off at 7.30 and it was after midnight before we had got back behind the line it had been decided to hold and could get the wounded men off-loaded. Next morning they started off again and after travelling all day reached a field ambulance dressing station where they could be dressed and fed. Here forty more camels with cacolets were available, and the day following (their third successive day of travel) the wounded were transported by these to a receiving station at Ramleh in the plains-a sort of advanced casualty clearing station where some sort of emergency surgical treatment was possible. A number had died on this long journey. The main C.C.S. was fifty miles away over rough unmetalled road and the nearest properly equipped hospital was 130 miles farther on the Suez Canal. Few, if any, casualties reached that within a week of being wounded. 
Contrast this with the conditions of the Burma campaign in the winter and spring of 1944-5. I was then commanding a British Field Hospital, which after being overrun by the Japanese near Imphal in April, 1944, had been flown back to Assam. By the time the Fourteenth Army advanced again in the autumn of that year and captured Mandalay it was hundreds of miles from its railhead, connected therewith only by a jungle road; so that its ammunition, supplies and reinforcements had to be conveyed entirely by air. That made the convoy of all casualties by air not only possible but necessary and their evacuation was on these lines. Bulldozers operated at brigade level, and while a battle was in progress they knocked down the little dykes separating the level ricefields and prepared in an hour or two a landing ground a few hundred yards long, enough for light L.5 aeroplanes to land. Casualties on stretchers were loaded on to jeeps which then ran down to the new airstrip and transferred them to the L.5s. These would then take off with one case each and land at a larger airfield (constructed previously by the Japs) where a C.C.S. and forward surgical unit would be stationed. This journey might take one-quarter of an hour or more. Some cases needing immediate operation, such as abdominal wounds, were detained at the C.C.S., so were very light wounds and cases of sickness likely to be fit for duty within a week. But the rest were loaded forthwith into Dakotas, which took about forty casualties each, and flown straight back, "over the hump" as we called the high ranges bordering Burma, to my hospital in Assam. So that a man shot through the head in a dawn attack was on our operating table at six o'clock the same evening, having travelled 500 miles or more.

The effect of this rapid evacuation on the healing of wounds was dramatic. Every wounded man received three-hourly injections of penicillin, so that no wounds became septic; blood or plasma transfusions were available for all requiring them so that the effects of shock were largely eliminated ; fractures were immobilized on the day they occurred and remained so till union had taken place. Most striking of all were the results on the morale of the men and their confidence of recovery. Men when first wounded often seem surprisingly little affected : they may march a mile or more on a leg that is subsequently amputated. It is half a day later that the reaction and shock are made manifest. In Burma the men by that time were on a hospital bed, after a few hours' rest in the plane, with an English nurse taking their pulse and the patients in neighbouring beds assuring them, "Cheer up, chum; no one ever dies in this 'ere 'orspital!" I often heard that remark when I was watching the admission of convoys, and it was not far from the truth, for death. was a rare occurrence. We were the most forward of the British Field Hospitals and received nearly all the British casualties evacuated from Burma during the period of heavy fighting; in the final phase of the advance on Rangoon many were evacuated by sea. We detained all dangerously wounded cases and passed on most of the others to hospitals in our rear so as to have beds available for the daily convoys. In the first war, hospitals filling such a role and dealing with wounded evacuated under the conditions I have described in Palestine expected a death-rate of 
5 to 10 per cent. In the Burma campaign we admitted over 11,000 casualties in five months, and might have expected-in the conditions of 1914-18 - perhaps a thousand deaths. Our actual deaths in that period numbered 23. That figure illustrates more eloquently than any words the difference in the medical services of the two wars. It is the more surprising since we were working in a very trying climate in a temperature that seldom fell below $90^{\circ} \mathrm{F}$. with a 90 per cent. humidity. Our wards were overcrowded canvas marquees, our amenities non-existent. But we had erected an adequate operating theatre, built of mud bricks in a month and air-conditioned by a plant requisitioned in Calcutta, and that made all the difference to the surgeons and to the wounded. 